\title{
THE CONFORMATION OF THE BRAIN PLAYS AN IMPORTANT ROLE IN THE DISTRIBUTION OF DIFFUSE AXONAL INJURY IN FATAL ROAD TRAFFIC ACCIDENT
}

\author{
José Eymard Homem Pittella1, Sebastião Nataniel da Silva Gusmão²
}

\begin{abstract}
Objective: A study was made of the brain lesions in 120 random victims of fatal road traffic accidents to determine the frequency and topographic distribution of diffuse axonal damage (DAI) in relation to the midline brain structures. M ethod: The identification of axons was carried out with a mouse antibody anti-neurofilament proteins 70-, 160-, and 210-kD. Results: DAI was identified in $96(80 \%)$ brains and classified as Grade 1 in $21.9 \%$, as Grade 2 in $51 \%$, and as Grade 3 in $27.1 \%$ of the patients. In spite of the diffuse distribution that is characteristic of DAI, damage occurred preferentially in the interhemispheric formations (corpus callosum and fornix) and rostral portion of the brainstem, usually to one side of the midline. Conclusion: From a mechanical point of view, the interhemispheric formations and the rostral portion of the brainstem act as fixating structures for the cerebral hemispheres during rotational acceleration of the head. It is known that the motion of the cerebral hemispheres is delayed at the points of fixation, where greater stress would be produced, particularly on the side subjected to greater displacement. The frequent involvement by DAI of deep, center-medial brain structures, usually to one side of the midline, supports the mechanism proposed above.
\end{abstract}

KEY WORDS: diffuse axonal injury, head injury, road traffic accident, biomechanics.

\begin{abstract}
A conformação do encéfalo é um fator importante na distribuição da lesão axonal difusa no acidente de trânsito fatal

RESUM 0 - Objetivo: Foram estudadas as lesões encefálicas de 120 vítimas fatais de acidentes de trânsito, selecionadas aleatoriamente, com a finalidade de determinar a freqüência e distribuição topográfica da lesão axonal difusa (LAD) em relação com as estruturas encefálicas da linha média. Método: A identificação dos axônios foi efetuada com antisoro anti-proteínas do neurofilamento 70-, 160- e 210-kD obtido em camundongo. Resultados: A LAD foi observada em 96 (80\%) dos encéfalos examinados, tendo sido classificada em Grau $1 \mathrm{em} \mathrm{21,9 \% ,} \mathrm{Grau} 2$ em 51\% e Grau 3 em 27,1\% dos pacientes. A despeito da distribuição difusa que é característica da LAD, a lesão afetou preferencialmente as formações inter-hemisféricas (corpo caloso e fórnix) e a porção rostral do tronco encefálico, usualmente em um dos lados da linha média. Conclusão:As formações inter-hemisféricas e a porção rostral do tronco encefálico funcionam, do ponto de vista mecânico, como estruturas de fixação dos hemisférios cerebrais durante a aceleração rotacional da cabeça. Sabe-se que a movimentação dos hemisférios cerebrais é retardada nas áreas de fixação, gerando aí maior estresse, particularmente no lado submetido ao maior deslocamento. 0 frequente envolvimento pela LAD das estruturas encefálicas centro-mediais profundas, usualmente em um dos lados da linha média, favorece o mecanismo acima proposto.
\end{abstract}

PALAVRAS-CHAVE: lesão axonal difusa, trauma crânio-encefálico, acidente de trânsito, biomecânica.

Diffuse axonal injury (DAI) is a consistent feature of traumatic brain injury following long duration, high speed acceleration or deceleration, as occurs in road traffic accidents, falls and some sports injuries ${ }^{1-3}$. DAl is currently considered as the most important factor in determining the morbi-mortality in non-missile head trauma. Not only is it the most common cause of post-traumatic coma in the absence of an intracranial expand- ing lesion and of vegetative state, but also of disability after head injury ${ }^{1,4-7}$.

Since the original descriptions of DAI using classic silver impregnation methods, and more recently using immunostaining techniques, emphasis was placed on the concentration of axonal damage in and around midline structures, namely, the corpus callosum, the parassagittal white matter and in the ros-

Laboratory of Neuropathology, Department of Pathology and Forensic M edicine ${ }^{1}$ and Department of Neurology and Psychiatry², School of M edicine, Federal University of Minas Gerais, M inas Gerais, Belo Horizonte MG Brazil: ${ }^{1 M}$. D., Professor, ${ }^{2}$ M. D., Associate Professor. This study was supported by grant $302036 / 76$ (Dr. JEH Pittella) from Conselho Nacional de Desenvolvimento Científico e Tecnológico (CNPq) and by Fundação de Amparo a Pesquisa do Estado de M inas Gerais (FAPEM IG).

Received 10 September 2003, received in final form 27 Novembro 2003. Accepted 8 January 2004.

Dr. José Eymard Pittella - Rua dos Otoni 712/304 - 30150-270 Belo Horizonte M G - Brasil. E-mail: pittella@medicina.ufmg.br 
tral brainstem ${ }^{2,5,8-14}$. The amount and topographic distribution of DAI has been explained based on the centripetal progression of strains to the core of brain ${ }^{15}$, and on the concentration of tensile and shear strains on the central brain and brainstem determined in part by the compartmentalization of the intracranial cavity by the falx cerebri and tentorium cerebel$\mid \mathrm{i} 7,16,17$.

In this study, a morphological analysis is made of the macro and microscopic brain lesions in 120 individuals that died due to road traffic accidents, regardless of their period of survival after the head injury. The purpose of this study is to determine the frequency and topographic distribution of diffuse axonal damage in relation to the midline brain structures and to propose a mechanism that would explain the correlation between the topography of DAI and the distribution of predicted deformations as related with the conformation of the brain, when the head is submitted to rotational acceleration.

\section{METHOD}

Patients - One hundred and twenty random victims of road traffic accidents, who had sustained either a motor vehicle accident (51 patients), or an auto-pedestrian injury (69 patients), autopsied in the period between 1989 and 1993, in the Institute of Legal M edicine, Belo Horizonte, M inas Gerais, Brazil, were studied. Both the victims that had died after being admitted to the hospital and those whose death had occurred at the site of the accident or before admission were included. The state of consciousness on hospital admission was evaluated by the Glasgow coma scale (GCS) established by Teasdale $\&$ J ennett ${ }^{18}$. The autopsies were performed within 24 hours of death. Complete postmortem examinations were performed in every case. After the trunk and limbs had been examined, the external lesions on the head and neck were described, followed by removal of the brain and description of the bone and intracranial lesions found.

Neuropathology - In all 120 patients the neuropathological examination was performed by the same pathologist (JEH Pittella). The brains were suspended in $10 \%$ formalin solution for a minimum period of three weeks. After the external brain surface had been described, frontal sections through the cerebral hemispheres, horizontal sections through the brainstem, sagittal sections through the left cerebellar hemisphere, and oblique sections through the right cerebellar hemisphere were made. The sections were separated by $10 \mathrm{~mm}$ intervals at cerebral hemispheres level and by $5 \mathrm{~mm}$ intervals at brainstem and cerebellum levels.

Fragments for microscopic examination were taken from the frontal, parietal, temporal and occipital lobes, corpus callosum (at three levels: genu, midlevel and splenium), fornix, basal ganglia, thalamus, hypothalamus, midbrain, pons, medulla, and cerebellar hemispheres. The fragments were processed for paraffin-embedding, cut into $7 \mu \mathrm{m}$ thick-sections and stained by hematoxylin-eosin to assess the severity and distribution of any microscopic changes such as hemorrhages and hypoxic-ischemic damage. In addition, frontal sections from both sides of the brain, including parasagittal regions of the frontal lobes, basal ganglia and internal capsule, corpus callosum (at three levels: genu, midlevel and splenium), anterior commissure, and fornix and horizontal sections of the brainstem were also processed for paraf- fin-embedding, cut into $7 \mu \mathrm{m}$ sections and stained for the identification of axons with a monoclonal mouse antibody anti-neurofilament proteins 70-, 160-, and 210-kD (Dianova-Immunotech, Hamburg, Germany) at a dilution of 1:200. The sections were incubated for two hours at $4^{\circ} \mathrm{C}$. Following primary antibody incubation, the sections were incubated for one hour in goat anti-mouse antibody (Sigma Chemical Company, St Louis, M O, USA) at a dilution of 1:100. Then, the sections were incubated for one hour in mouse peroxidase-antiperoxidase (Sigma Chemical Company, St Louis, MO, USA) at a dilution of $1: 100$. For the visualization of the reaction product, the sections were reacted in $0.05 \% 3,3$ diaminobenzidine tetrahydrochloride (DAB) and $\mathrm{H}_{2} \mathrm{O}_{2}$. The histological sections were counterstained with hematoxylin. For positive controls histological sections of normal brains were used. For negative controls, the phosphate buffer solution or normal mouse serum were used instead of the primary antibody.

Identification and grading of DAI - Axonal injury was considered as evidence of DAI when axonal swellings and bulbs were diffusely distributed throughout the brain, although preferentially located in the corpus callosum, the fornix, the internal capsule, the cerebral white matter and the rostral brainstem ${ }^{8,12}$. Axonal injury around focal lesions (hemorrhages, contusions, infarcts) were not considered as DAl.

DAI was graded according to the criteria proposed by Adams et al. ${ }^{1:}$ grade 1 - presence of axonal swellings and bulbs; grade 2 - presence of hemorrhagic lesion in the corpus callosum; grade 3 - presence of primary hemorrhagic lesion in the dorsolateral quadrant of the rostral brainstem. In those patients that died at the site of the accident or before reaching hospital or that had died immediately after being admitted to the hospital, the presence of DAI was assigned by the finding of hemorrhagic lesion (macro or microscopically) in the corpus callosum and/or in the dorsolateral quadrant of the rostral brainstem. Isolated or sparse focal hemorrhages, anywhere, were not considered as DAI. Also, focal hemorrhagic lesions in the midline of the tegmentum of the midbrain and pons secondary to increased intracranial pressure (Duret's hemorrhage) were not considered as DAI ${ }^{19-21}$.

\section{RESULTS}

Clinical findings - The age range of the 120 patients was from 2 to 88 years and the mean age was $37.5 \pm 18.3$ years. There were 90 (75.0\% ) males and 30 (25.0\%) females. Eightythree patients $(69.2 \%)$ survived for less than one day after the accident: 41 patients (34.2\%) died at the site of the accident and $42(35 \%)$ after hospital admission; the remaining 37 $(30.8 \%)$ survived between 1 and 28 days at the hospital.

Neuropathological findings - DAI was seen in 96 (80.0\%) patients. Table 1 shows the frequency of the various head and extracranial lesions found in the 96 patients with DAI. Cerebral contusion, skull fracture and morphological signs of increased intracranial pressure were the most common head lesions, whereas thoracic-abdominal trauma and limb fracture were the most common extracranial lesions found. In those patients that died at the site of the accident or very early after hospital admission, the cause of death was attributed to head trauma and/or increased intracranial pressure, internal hemor- 


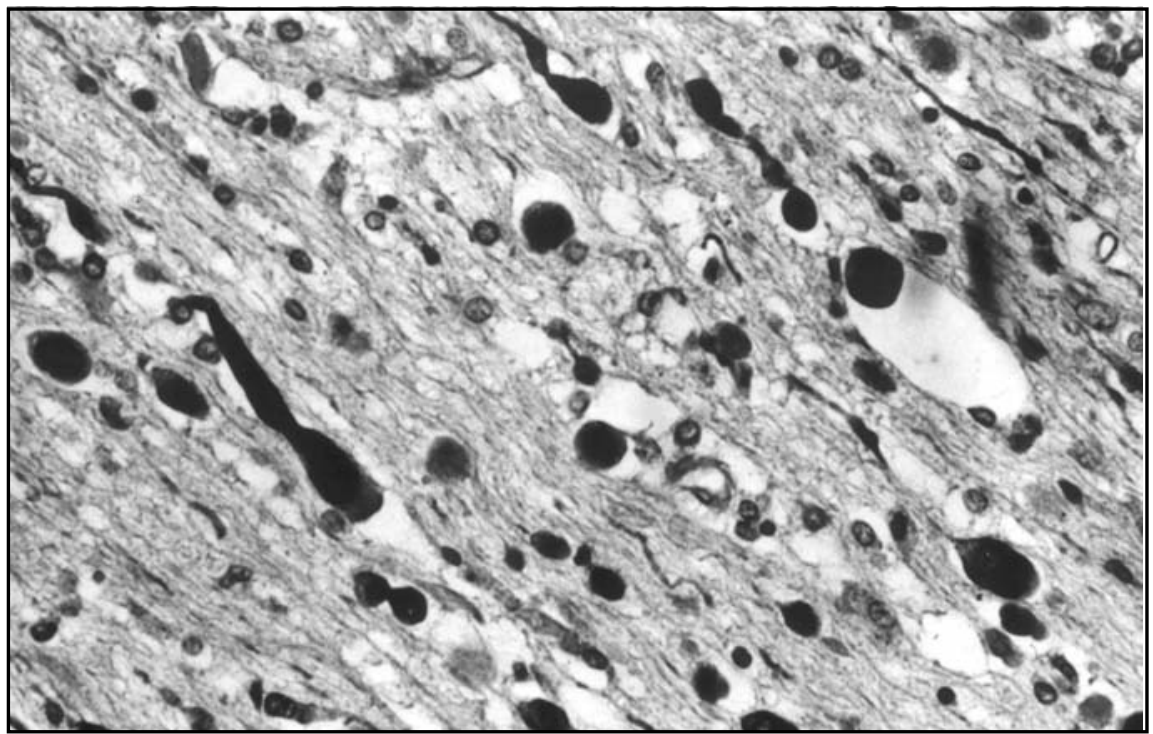

Fig 1 Diffuse axonal injury. Axonal swellings and bulbs in the corpus callosum. PAP, antineurofilament proteins and hematoxylin counterstaining, X450.

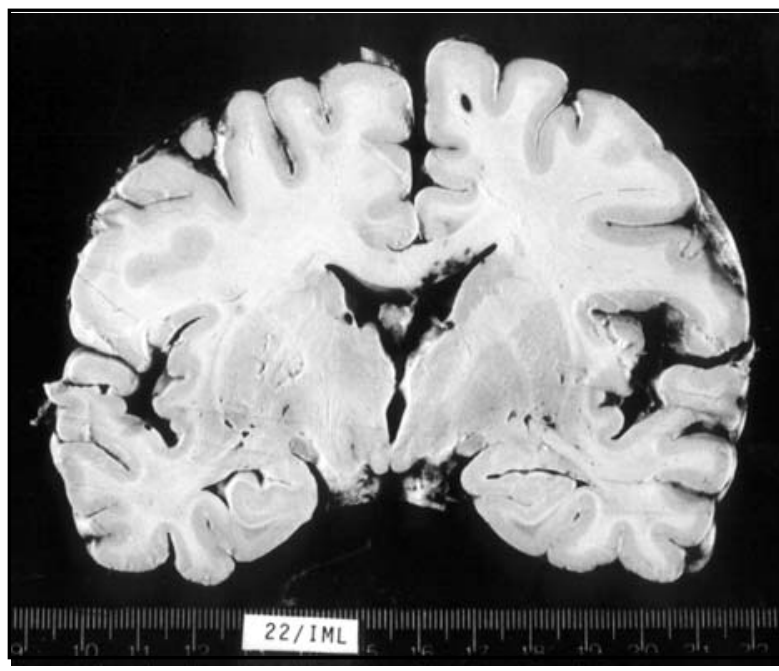

Fig 2. Diffuse axonal injury. There is multiple small hemorrhage foci in the inferior part of the corpus callosum to the left of the midline.

rhage, and multiple fractures. On the other hand, head trauma, increased intracranial pressure, hypoxic brain damage and pneumonia, either isolated or in association, were the cause of death in the patients that survived between 1 and 28 days.

Grading and topographic distribution of DAI - DAI was graded 1 in $21(21.9 \%)$ patients, 2 in $49(51,0 \%)$ patients and 3 in $26(27.1 \%$ ) patients. Axonal swellings and bulbs (Fig 1) were found in $54(56.3 \%)$ patients (Table 1). Hemorrhagic lesions in the corpus callosum and in the dorsolateral quadrant of the rostral brainstem (Figs 2 and 3) were identified in 75 (78.1\%) and $26(27.1 \%$ ) patients, respectively (Table 1$)$. In the corpus callosum there were gross and microscopic hemorrhages in

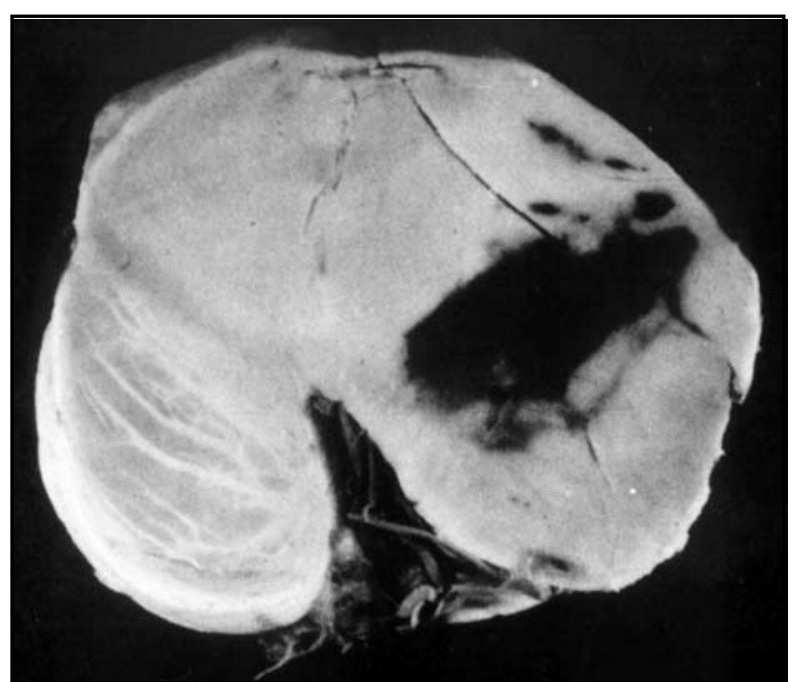

Fig 3. Diffuse axonal injury. Section at the level of the pontomesencephalic junction showing a hemorrhagic lesion in the left dorsolateral quadrant.

$39.2 \%$ and $60.8 \%$ of the patients, whereas in the dorsolateral quadrant of the rostral brainstem gross and microscopic hemorrhages were found in $57.6 \%$ and $42.4 \%$ of the patients, respectively. Axonal swellings and bulbs were diffusely distributed throughout the brain, but were preferentially located in the corpus callosum and rostral brainstem (Table 2). The distribution of focal hemorrhagic lesions and of the damage to axons in the corpus callosum and the rostral brainstem was markedly one-sided (Tables 3 and 4). Also, the distribution of the axonal injury in the cerebral white matter, the internal capsule, the fornix and the anterior commissure was markedly onesided or asymmetrical. Of the 64 hospitalized patients with DAI, 
Table 1. Head and extracranial lesions in 96 patients with diffuse axonal injury.

\begin{tabular}{lll}
\hline Pathological findings & $\mathrm{n}$ & $\%$ \\
\hline Axonal swellings and bulbs & 54 & 56.3 \\
Hemorrhage in the corpus callosum & 75 & 78.1 \\
Hemorrhage in the brainstem* & 26 & 27.1 \\
Hemorrhage of the fornix & 43 & 44.8 \\
Intraventricular hemorrhage & 23 & 24.0 \\
Diffuse vascular injury & 14 & 14.6 \\
Cerebral contusion & 60 & 62.5 \\
Extradural hematoma & 7 & 7.3 \\
Acute subdural hematoma & 15 & 15.6 \\
Intracerebral hematoma & 10 & 10.4 \\
Burst lobe & 12 & 12.5 \\
Hypoxic brain damage & 22 & 22.9 \\
Morphological signs of increased IP & 37 & 44.8 \\
Skull fracture & 43 & 57.3 \\
Thoracic-abdominal trauma & 55 & 46.9 \\
Limb fracture & & 16.7 \\
Pneumonia & & \\
\hline
\end{tabular}

*dorsolateral quadrant of the rostral brainstem.

$\mathbb{I P}$, intracranial pressure.
Table 2. Topographic distribution of axonal swellings and bulbs in 96 patients with diffuse axonal injury.

\begin{tabular}{lll}
\hline Location & $\mathrm{n}$ & $\%$ \\
\hline Cerebral white matter & 26 & 27.1 \\
Internal capsule & 32 & 33.3 \\
Corpus callosum & 49 & 51.0 \\
Fornix & 22 & 22.9 \\
Anterior commissure & 19 & 19.8 \\
Rostral brainstem & 50 & 52.1 \\
\hline
\end{tabular}

$56(87.5 \%)$ were in a state of coma (Glasgow coma scores of 3 to 8 ) and eight (12.5\%) had Glasgow coma scores of 9 to 15. All these eight patients had less severe DAI (grade l: five patients; grade II: three patients).

\section{DISCUSSION}

Identification of axonal injury - The identification of axonal injury can be made by hematoxylin-eosin staining and silver impregnation or by immunohistochemical techniques that use antibodies to the $\beta$-amyloid precursor protein ${ }^{2,12,13,22,23}, 68$ , 170- and 200-kDa neurofilament proteins ${ }^{10,24}$, and other axonally transported proteins. The immunohistochemical techniques are comparatively much more sensitive than the conventional silver impregnation to demonstrate axonal injury ${ }^{10,13}$.

Table 3. Distribution of hemorrhagic lesions in the corpus callosum and dorsolateral quadrant of the rostral brainstem in relation to the midline in 96 patients with diffuse axonal injury.

\begin{tabular}{lcccc}
\hline Distribution & \multicolumn{2}{c}{ Corpus callosum } & \multicolumn{2}{c}{ Dorsolateral rostral brainstem } \\
& $\mathrm{n}$ & $\%$ & $\mathrm{n}$ & $\%$ \\
\hline Bilateral & 12 & 16.0 & 8 & 30.8 \\
One-sided & 61 & 81.3 & 18 & 69.2 \\
Median & 2 & 2.7 & - & - \\
Total & 75 & 100 & 26 & 100 \\
\hline
\end{tabular}

Table 4. Distribution of axonal swellings and bulbs in the corpus callosum and the rostral brainstem in relation to the midline in 96 patients with diffuse axonal injury.

\begin{tabular}{lcccc}
\hline Distribution & \multicolumn{2}{c}{ Corpus callosum } & \multicolumn{2}{c}{ Rostral brainstem } \\
& $\mathrm{n}$ & $\%$ & $\mathrm{n}$ & $\%$ \\
\hline Bilateral & 3 & 6.1 & 4 & 8.00 \\
One-sided & 45 & 91.9 & 46 & 92.0 \\
Median & 1 & 2.0 & - & - \\
Total & 49 & 100 & 50 & 100 \\
\hline
\end{tabular}


These studies indicated that the frequency of axonal injury has probably been underestimated using silver impregnation and that axonal injury may in fact be an almost universal consequence of fatal head injury ${ }^{7,13}$. In addition, neurofilament proteins and the $\beta$-amyloid precursor protein have been show $\mathrm{n}$ to be effective markers of axonal damage in the form of focal axonal swellings within the first 1-2 hours after head injury ${ }^{9,12}$, whereas by the conventional histological techniques of hematoxylin-eosin and silver impregnation it is not possible to identify with certainty axonal bulbs until about $15 \mathrm{~h}$ after injury ${ }^{14}$. In a comparative study using antibodies to nine different antigens (including $\beta$-amyloid precursor protein and neurofilament protein), immunostaining for $\beta$-amyloid precursor protein produced the most sensitive and reliable staining of axonal injury ${ }^{23}$, although the authors used an antibody targeted exclusively to the 68-kDa neurofilament subunit.

Topographic distribution of DAI - In immunohistochemical studies, the regions most frequently affected and containing the largest number of axonal swellings and bulbs were the corpus callosum, the internal capsule, the fornix, the midbrain and the pons ${ }^{9-13}$, such findings being very similar to those reported by Adams et al. ${ }^{8}$ and Adams ${ }^{25,26}$ and by those of the patients in our series.

DAI, in the form of both hemorrhagic lesions and injured axons, showed a distinct tendency for one-sided concentration in the interhemispheric structures and rostral portion of the brainstem. According to Adams et al. ${ }^{1}$ and Graham et al. ${ }^{14}$, the focal lesion in the corpus callosum is typically hemorrhagic, generally occurring in the inferior part of the corpus callosum and on one or other side of the midline, although it may extend to the midline and involve the interventricular septum and the pillars of the fornix. Intraventricular hemorrhage can be found when there is disruption of the interventricular septum ${ }^{6}$. The focal hemorrhagic lesion in the dorsolateral quadrant of the rostral brainstem is usually identified in the dorsolateral part of the midbrain and the rostral pons ${ }^{14}$. When bilateral, one lesion is usually larger than the other. As in our series, in many patients the focal lesion in the corpus callosum and dorsolateral rostral brainstem is identifiable only microscopically $y^{1,10}$. Following the same pattern of the focal hemorrhagic lesion, the distribution of the damage to axons in the corpus callosum, the cerebral white matter, the cerebellum and the brainstem is not uniform or symmetrical ${ }^{14}$. Also worth noting is the high frequency of center-medial lesions associated with DAI in our series: hemorrhage in the fornix, and intraventricular hemorrhage.

Biomechanics of DAI - Since DAI is a primary lesion 25,27 caused by shearing forces, it can be admitted that its distribution is explainable by the application of physical laws ${ }^{28,29}$.
The biomechanics of DAI has been discussed for nearly three decades $^{7,14-17}$ (see, too, review of the literature in Goldsmith ${ }^{30}$ and Meythaler et al. ${ }^{3}$ ). Based on the experimental results obtained by Holbourn ${ }^{28,29}$ with a spheroid brain model and on their own experiments ${ }^{31-33}$, Ommaya \& Gennarelli ${ }^{15}$ proposed that the inertial strains produced by angular acceleration affect the brain in a centripetal progression, i.e., the damaging force would decrease as it is transmitted from the surface to the center of the brain. Based on that hypothesis, the authors concluded that center brain lesions are rare because centripetal force of sufficient intensity to reach that region is infrequent and, when present, would be associated with lesions in the periphery of the brain.

However, the results obtained by Tomlinson ${ }^{19}$, Crompton ${ }^{20}$, Rosenblum et al. ${ }^{34}$, Grcevic ${ }^{16}$, Adams et al. ${ }^{1}$, and from our own series confirm that lesions in the brainstem and center-median brain structures (corpus callosum and fornix) are quite frequent in fatal head trauma. Such high frequency was not expected taking in consideration the decrease in the traumatic strains as they progress from the surface to the center of the brain.

The hypothesis advanced by Ommaya \& Gennarelli ${ }^{15}$ was developed based on a spheroid brain model. The brain is better reproduced, however, not by a homogeneous spheroid, but by two large semi-spheroids (the cerebral hemispheres) interconnected at the central portion of their medial faces by narrow interhemispheric formations (corpus callosum, fornix and septum pellucidum) and connected to the brainstem inferiorly by the cerebral peduncles. Relative fixation of the brainstem is provided anteriorly by the perforating vessels that originate from the basilar artery, and posterolaterally by the cerebellum. Besides, the anterior surface of the pons and the basilar artery rest on the basilar portion of the occipital bone and the dorsum sellae of the sphenoid (clivus). The cerebral hemispheres, on the contrary, are relatively more subject to rotational movement ${ }^{35}$. Thus, from a mechanical point of view, the interhemispheric formations and the rostral portion of the brainstem act as fixating structures for the hemispheres during movement of the brain within the skull.

The shape and points of fixation of a body subjected to rotational acceleration are fundamental in the distribution of shearing stresses ${ }^{36}$. On the shape will depend the axis of rotation and, therefore, the distribution of torque. At the point of fixation, rotational movement will be delayed (due to the torque produced by the reaction forces acting at these points), with consequent stress concentration and deformation at these points. Because of the conformation of the brain, independent and complementary displacements of the hemispheres occur during rotation of the head ${ }^{35}$. It is know $n$ that such differential motions are delayed at the points of fixation of the hemispheres, with greater stress being produced in these 
areas, particularly on the side subjected to greater displacement. On the other hand, acceleration of the brain in the coronal plan would lead to greater stress in the rostral and lateral portion of the brainstem, much in the same manner as the acceleration of the crown of a tree would cause greater stress, and possibly deformation, at the level of the tree's trunk (Fig 4).

According to Grcevic ${ }^{16}$, Graham \& Gennarelli ${ }^{7}$ and Graham et al. ${ }^{14}$, the direction in which the head moves plays an important role in the amount and distribution of vascular and axonal damage in a given situation. For equivalent levels of angular acceleration, the brain is most vulnerable if it is moved laterally. When the entire head undergoes rotational acceleration, in certain locations in the central brain and brainstem, portions of the brain move in opposite directions, thus generating shear and tensile strains. The maximum deformation is in midline structures determined in part by the compartmentalization of the intracranial cavity by the falx and tentorium ${ }^{7,16}$. It is these regions that show the greatest and most consistent amounts of tissue tear hemorrhages and axonal injury. Similar conclusions were reported by Nishimoto $\&$ M urakami ${ }^{17}$ based on head models submitted to direct impact with translational acceleration.

It is possible, however, that the own conformation of the brain, as above explained, and not the compartmentalization of the intracranial cavity, can be the main responsible for the concentration of tensile and shear strains on the central brain and rostral brainstem during rotational acceleration of the head. In fact, a distinct pattern of lesions, influenced by the fal $x$ and by the tentorium, follow to the presence of a supratentorial expanding mass lesion accompanied by increased intracranial pressure, deformation and shift of the brain and the appearance of internal herniae ${ }^{37,38}$. Expansion of a mass in the frontal or parietal lobe lead to depression of the corpus callosum on the same side and herniation of whole or part of the cingulate gyrus under the the free edge of the falx. The latter produces an indendation or, occasionally, a wedge of pressure necrosis along the dorsal border of the herniated gyrus $5^{37-39}$.

On the other hand, herniation of part or whole of the parahippocampal gyrus medially and downward through the tentorial opening results in deformation and compression of the midbrain ${ }^{37-39}$. The contralateral cerebral peduncle is pushed against the rigid, free tentorial edge, leading to infarction with or without hemorrhage in the dorsal part of the pedun$\mathrm{cle}^{40}$. Hemorrhage and infarction occur adjacent to the midline in the tegmentum of the midbrain and in the tegmental and basal parts of the pons (Duret's hemorrhage). These latter lesions are more likely the result of downwards displacement and anterior-posterior elongation of the rostral brainstem caused by side-to-side compression by the tentorial hernia, coupled with relative immobility of the basilar artery. In these situations of deformity, compression and shift of the brain, nerve tissue injury induced by contact with the falx and the tentorium does not produce focal hemorrhagic lesions in the corpus callosum and in the dorsolateral sector of the rostral brainstem.

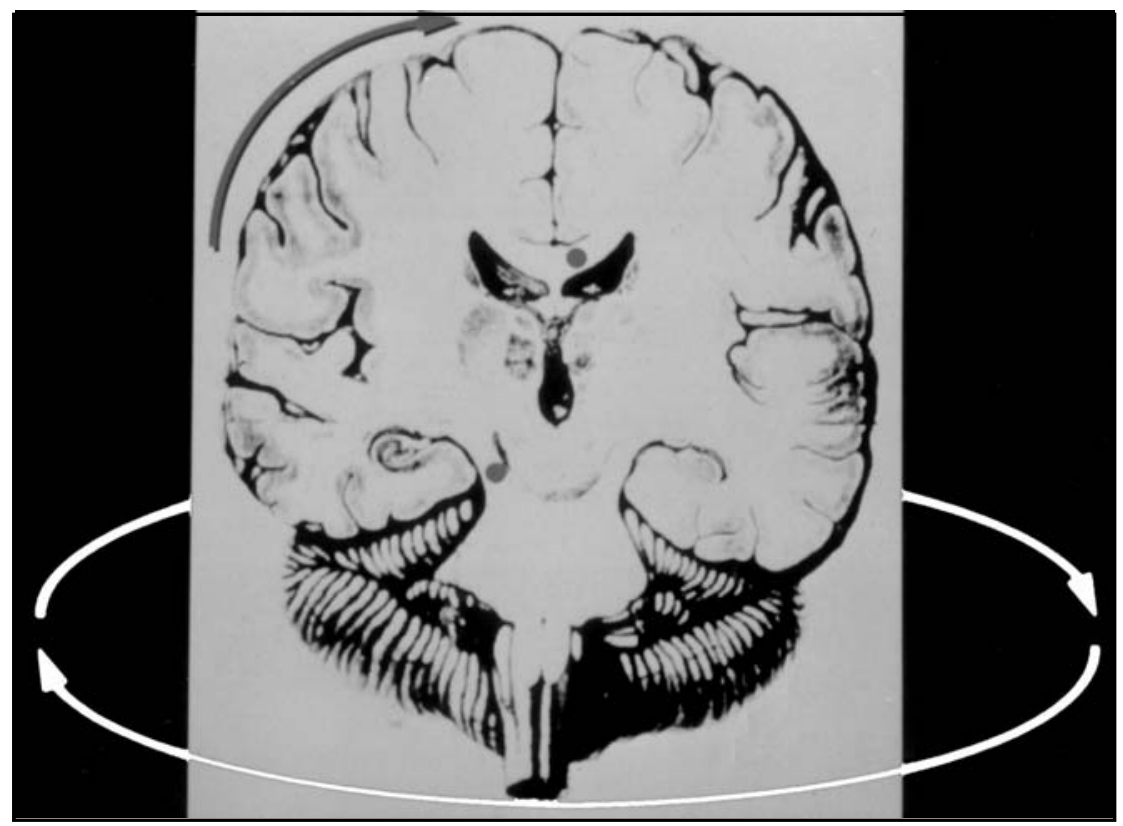

Fig 4. Schematic coronal view of the brain illustrating the brain movement that occurs when the head is submitted to rotational acceleration. The arrows indicate the local movement of the brain. See text for explanation. 


\section{CONCLUSION}

The frequent involvement of deep, center-median brain structures (corpus callosum, fornix, and rostral brainstem), usually to one side of the midline, cannot be explained merely either by the centripetal distribution of shearing stress during trauma or the concentration of tensile and shear strains on the central brain and brainstem determined in part by the compartmentalization of the intracranial cavity by the falx cerebri and tentorium cerebelli. Our results show that it is the own conformation of the brain that makes these structures particularly vulnerable to deformation by shear strains during rotational acceleration of the head.

\section{REFERENCES}

1. Adams JH, Doyle D, Ford I, Gennarelli TA, Graham DI, McLellan DR. Diffuse axonal injury in head injury: definition, diagnosis and grading. Histopathology 1989;15:49-59.

2. Abou-Hamden A, Blumbergs PC, Scott G, et al. Axonal injury in falls. J Neurotrauma 1997;4:699-713.

3. Meythaler JM, Peduzzi JD, Eleftheriou E, Novack TA. Current concepts: diffuse axonal injury-associated traumatic brain injury. Arch Phys Med Rehabil 2001;82:1461-1471.

4. Jennett B, Plum F. Persistent vegetative state after brain damage. Lancet 1972;1:734-737.

5. Adams JH, Graham DI, Murray LS, Scott G. Diffuse axonal injury due to non-missile head injury in humans: an analysis of 45 cases. Ann Neurol 1982;12:557-563.

6. Graham DI, Adams JH, Nicoll JAR, Maxwell WL, Gennarelli TA. The nature, distribution and causes of traumatic brain injury. Brain Pathol 1995;5:397-406.

7. Graham DI, Gennarelli TA. Trauma. In Graham DI, Lantos PL (eds). Greenfield's neuropathology. 6 Ed. London: Arnold, 1997:197-262.

8. Adams JH, Graham DI, Scott G, Parker L, Doyle D. Brain damage in fatal non-missile head injury. J Clin Pathol 1980;33:1132-1145.

9. Blumbergs PC, Jones NR, North JB. Diffuse axonal injury in head trauma. J Neurol Neurosurg Psychiatry 1989;52:838-841.

10. Ng HK, Mahaliyana RD, Poon WS. The pathological spectrum of diffuse axonal injury in blunt head trauma: assessment with axon and myelin stains. Clin Neurol Neurosurg 1994;96:24-31.

11. Sherriff FE, Bridges LR, Sivaloganathan S. Early detection of axonal injury after human head trauma using immunocytochemistry for b-amyloid precursor protein. Acta Neuropathol 1994;87:55-62.

12. Blumbergs PC, Scott G, Manavis J, et al. Topography of axonal injury as defined by amyloid precursor protein and the sector scoring method in mild and severe closed head injury. J Neurotrauma 1995;12:565-572.

13. Gentleman SM, Roberts GW, Gennarelli TA, et al. Axonal injury: a universal consequence of fatal closed head injury? Acta Neuropathol 1995;89:537-543.

14. Graham DI, Gennarelli TA, McIntosh TK. Trauma. In Graham DI, Lantos PL (eds). Greenfield's neuropathology. 7. Ed. London: Arnold, 2002:823-898.

15. Ommaya AK, Gennarelli TA. Cerebral concussion and traumatic unconsciousness: correlation of experimental and clinical observations on blunt head injuries. Brain 1974;97:633-654.

16. Grcevic N. I. Head injury: the concept of inner cerebral trauma. Scand J Rehab Med Suppl 1988;17:25-31.

17. Nishimoto T, Murakami S. Relation between diffuse axonal injury and internal head structures on blunt impact. J Biomech Eng 1998;120:140-147.

18. Teasdale G, Jennett B. Assessment of coma and impaired consciousness: a practical scale. Lancet 1974;2:81-84.

19. Tomlinson BE. Brain-stem lesions after head injury. J Clin Pathol 1970;23 (Suppl 4):154-165.

20. Crompton R. Brainstem lesions due to closed head injury. Lancet 1971;3:669-673.

21. Pittellla JEH, Gusmão SNS. Diffuse vascular injury in fatal road traffic accident victims: its relationship to diffuse axonal injury. J Forensic Sci 2003;48:626-630.

22. Gentleman SM, Nash MJ, Sweeting CJ, Graham DI, Roberts GW. bAmyloid precursor protein (b-APP) as a marker of axonal injury after head injury. Neurosci Lett 1993;160:139-144.

23. Sherriff FE, Bridges LR, Gentleman SM, Sivaloganathan S, Wilson S. Markers of axonal injury in post mortem human brain. Acta Neuropathol 1994;88:433-439.

24. Grady MS, McLaughlin MR, Christman CW, Valadka AB, Fligner CL, Povlishock JT. The use of antibodies targeted against the neurofilament subunits for the detection of diffuse axonal injury in humans. J Neuropathol Exp Neurol 1993;52:143-152.

25. Adams JH. Head injury. In Adams JH, Corsellis JAN, Duchen LW (eds). Greenfield's Neuropathology. 4 Ed. London: Edward Arnold, 1984:85-124.

26. Adams JH. Head injury. In Adams JH, Duchen LW (eds). Greenfiels's neuropathology, 5 Ed. New York: Oxford, 1992:106-152.

27. Strich SJ. Shearing of nerve fibers as a cause of brain damage due to head injury: a pathological study of twenty cases. Lancet 1961;2:443-448.

28. Holbourn AHS. Mechanics of head injuries. Lancet 1943;2:438-441.

29. Holbourn AHS. The mechanics of brain injuries. Br Med Bull 1945;3:147149.

30. Goldsmith $W$. The state of head injury biomechanics: past, present, and future. Part 1. Crit Rev Biomed Eng 2001;29:441-600.

31. Ommaya AK. Experimental head injury in the monkey. In Caveness HF, Walker AE (eds). Head injury. Philadelphia: Lippincott, 1966:260-275.

32. Ommaya AK. Trauma to the nervous system. Ann R Coll Surg Engl 1966;39:317-347.

33. Ommaya AK, Hirsch AE. Tolerances for cerebral concussion from head impact and whiplash in primates. J Biomech 1971;4:13-21.

34. Rosenblum WI, Greenberg RP, Seelig JM, Becker DP. Midbrain lesions: frequent and significant prognostic features in closed head injury. Neurosurgery 1981;9:613-620.

35. Pudenz $\mathrm{RH}$, Shelden $\mathrm{CH}$. The lucite calvarium: a method for direct observation of the brain. II. Cranial trauma and brain movement. J Neurosurg 1946;3:487-505.

36. Holbourn AHS. The mechanics of trauma with special reference to herniation of cerebral tissue. J Neurosurg 1944;1:190-200.

37. Miller JD, Adams JH. The pathophysiology of raised intracranial pressure. In Adams JH, Corsellis JAN, Duchen LW (eds). Greenfield's neuropathology. 4. Ed. London: Edward Arnold, 1984:53-84.

38. Ironside JW, Pickard JD. Raised intracranial pressure, oedema and hydrocephalus. In Graham DI, Lantos PL (eds). Greenfield's neuropathology. 7. Ed. London: Arnold, 2002:193-231.

39. Russell DS, Rubinstein LJ. Pathology of tumours of the nervous system. 3. Ed. London: Edward Arnold, 1971:273-283.

40. Kernohan JW, Woltman HW. Incisura of crus due to contralateral brain tumor. Arch Neurol Psychiatry 1929;21:274-287. 